\title{
BILATERAL OSSIFIED STYLOHYOID COMPLEX: A CASE REPORT
}

\author{
Sarada Devi S. Sattiraju1, Rajasree T. K
}

${ }^{1}$ Professor, Department of Anatomy, Malla Reddy Institute of Medical Sciences, Suraram Cross Roads, Jeedimetla, Hyderabad. 2 Professor \& HOD, Department of Anatomy, Malla Reddy Institute of Medical Sciences, Suraram Cross Roads, Jeedimetla, Hyderabad.

\begin{abstract}
Mineralisation of all components of stylohyoid complex or chain, a $2^{\text {nd }}$ branchial arch derivative is frequently reported. But bilateral occurrence of continuous bands of ossified tissue involving stylohyoid complex, are less commonly encountered. An adult skull specimen presented abnormally long osseous bands extending from base of skull in place of styloid process. On left side a band of $6.5 \mathrm{~cm}$ long $\times 1 \mathrm{~cm}$ wide and $0.3 \mathrm{~cm}$ in thickness, and on right side an irregularly rounded elongated structure of $7.5 \mathrm{~cm}$ length were noticed. Lower end of the left process was fused to hyoid bone. Either abnormally long styloid process or this type of ossified stylohyoid complex may be a causative factor for severe pharyngeal pain, dysphagia, may be a cause for occasional swelling in submandibular region or may be associated with Eagle syndrome. Due to its close proximity to tonsillar bed, if elongated it may be felt during tonsillectomy in tonsillar fossa. In this backdrop reports of this type may be of interest to clinicians.
\end{abstract}

KEYWORDS: Stylohyoid Complex, Stylo Hyoid Ligament, Branchial Arch, Eagle Syndrome.

HOW TO CITE THIS ARTICLE: Sarada Devi S. Sattiraju, Rajasree T. K. "Bilateral Ossified Stylohyoid Complex: A Case Report". Journal of Evolution of Medical and Dental Sciences 2015; Vol. 4, Issue 90, November 09; Page: 15598-15600,

DOI: $10.14260 /$ jemds/2015/2239.

INTRODUCTION: Stylohyoid complex [SHC] consists of styloid process, stylohyoid ligmant and lesser cornua of hyoid bone.1,2 These develop from $2^{\text {nd }}$ branchial arch. Reichert's cartilage, the cartilage of this arch ossifies to form styloid process, lesser cornu and upper part of hyoid bone. Between these two bones it becomes ligamentous and forms stylohyoid ligament. ${ }^{3}$ Reichert's cartilage is divided into a dorsal segment (Which forms stapes), tympanohyal, stylohyal, epihyal and ceratohyal. Segments. ${ }^{4}$ Stylohyoid chain or complex components are derived from these segments. ${ }^{5}$

\section{Components of Complex:}

Styloid Process: It is a slender bony process projecting antero inferiorly from inferior aspect of temporal bone. It varies in length from a few millimetres to $2.5 \mathrm{~cm}$ it is in relation to lateral pharyngeal wall. Proximal part is ensheathed by tympanic plate of temporal bone and muscles and ligaments are attached to its distal part. ${ }^{3}$ Laterally it is overlapped by parotid gland, and related to facial nerve and external carotid artery; medially related to internal jugular vein, IX, X, XI, XII cranial nerves and internal carotid artery. ${ }^{6}$

Development: Proximal part from tympanohyal and distal part from stylohyal segments.

Stylohyoid Ligament: Extends from styloid process to lesser cornu of hyoid bone. Derived from epihyal segment.

Financial or Other, Competing Interest: None.

Submission 15-10-2015, Peer Review 16-10-2015,

Acceptance 26-10-2015, Published 09-11-2015.

Corresponding Author:

Dr. Sarada Devi S. Sattiraju,

Professor, Department of Anatomy,

Malla Reddy Institute of Medical Sciences,

Suraram Cross Roads, Jeedimetla, Hyderabad-500055, Telangana.

E-mail: saradasattiraju@gmail.com

DOI:10.14260/jemds/2015/2239.
Lesser Cornu of Hyoid Bone: This projects from junction of body and greater cornu of hyoid bone. It gives attachments to stylohyoid ligament. It is derived from ceretohyal segment Ossified epihyal components continuous with stylohyal components gives the appearance of abnormally long styloid process.

Elongated styloid process and ossified stylohyoid complexes are reported entities.1,2,5,7,8,9 if length of styloid process exceeds $3 \mathrm{~cm}$ it is considered to be elongated and often found in $4 \%$ of individuals. 5,10 In $4 \%$ of individuals the ligament shows ossification. ${ }^{1}$

Although approximately $4 \%$ of the population is thought to have an elongated styloid process, only a small percentage (Between $4 \%$ and $10.3 \%$ ) of this group is thought to actually be symptomatic. ${ }^{11}$ If styloid process is felt in tonsillar fossa, it is indicative of elongation of process as normal length processes are not felt in this fossa. ${ }^{11}$

Attachment of various muscles and ligaments, proximity to important vessels and nerves and relation to pharynx and tonsillar fossa, make either abnormally long styloid process or ossified stylohyoid complex an important clinical entity.

MATERIAL: An adult dry skull specimen from teaching material of Osmania Medical College, Hyderabad presented abnormal elongated bony processes extending from base of skull bilaterally. [Figs. 1, 2, 3]

OBSERVATIONS: The specimen presented on either side two abnormally long bony processes extending from base of skull replacing styloid processes.

Left Side: Flat band of $6.5 \mathrm{~cm}$ long; $1.5 \mathrm{~cm}$ wide near base and $1.0 \mathrm{~cm}$ wide at lower end; and $0.3 \mathrm{~cm}$ in thickness was extending from base of skull (Replacing styloid process) to remains of hyoid bone, fusing with it. Upper part of band presented a ridge with downward and forward course and a depression behind and below the ridge. The part in front and above the ridge measured $2.5 \mathrm{~cm}$ (Fig. 1). 
Lower end of band attached to hyoid bone which is partly present. (Fig. 1).

Right Side: Slender long rounded process of $7.5 \mathrm{~cm}$ was extending from base of skull in place of styloid process. Lower end was free and presented a flat facet like slightly projecting mark. Right part of hyoid bone was destroyed and hence its attachment to bone could not be examined. It presented a groove on the surface which led to a blind foramen. The part above the groove measured $3.5 \mathrm{~cm}$ (Fig. 2).

There were no separate styloid processes, instead these continuous osseous bands replaced them. (Fig. 3).

DISCUSSION: Normal length of styloid process ranges between few millimetres to 2.5 centimeters. ${ }^{3}$ this range varies from author to author. It was quoted in literature. ${ }^{2}$ that normal range of length varied from $15.2 \mathrm{~mm}(1.5 \mathrm{~cm})$ to $47.7 \mathrm{~mm}(4.77 \mathrm{~cm})$. However it was considered as elongated if its length exceeds $30 \mathrm{~mm}(3 \mathrm{~cm})$. But others consider it elongated if length exceeds $40 \mathrm{mms}(4 \mathrm{~cm})$ It was quoted. ${ }^{12}$ that average length of $4.1 \pm 1: 1 \mathrm{~cm}$ or of $5 \mathrm{~cm}$ is given by some researchers. Stylohyoid complex ossification was reported by many. Osseous metaplasia of ligament may be asymptomatic or symptomatic. Reported incidence varies from 1.4 to $88.7 \%$ in asymptomatic individuals. ${ }^{8}$

This ossified complex was shown as a continuous band of osseous tissue extending from base of skull to hyoid bone lying on upper lateral neck. ${ }^{1}$ Bilateral ossification of this complex may be as low as $2.4 \%$ to as high as $84.4 \% .2,13$ Ossified epihyal components continuous with stylohyal components give the appearance of abnormally long styloid process. As per Rodriguz-Vanzque etal. ${ }^{14}$ in fetal period Reichertz's cartilage was found to have a cranial and caudal segments. As per their study on 50 human embryos (With exception of one specimen) no cartilage forms in central part of arch.

In embryonic period cranial and caudal segments were joined by mesenchymal tissue, but in later fetal period it disappears. As per their observations on human development there was no segmentation of cartilage into 4 components but reported only cranial and caudal segments which probably correspond to stylohyal and hypohyal segments (Styloid process and lesser horn of hyoid).

Skarzat etal..$^{2}$ described callosities on both stylohyoid complexes and those were regarded as ossified attachments of stylohyoid ligaments to corresponding styloid processes.

In present specimen a ridge and groove were observed on the processes almost at same levels on left and right sides respectively probably indicating level of attachments of ligaments. Proximal to ridge, left process measured $2.5 \mathrm{~cm}$ and proximal to groove right process measured $3.5 \mathrm{~cm}$ almost coinciding with normal length of styloid process.

Normal length styloid process is not felt in tonsillar fossa but if felt in this fossa it is considered as elongated.

Elongated styloid processes or minaralized stylohyoid chain were reported radiologically in routine investigations for related complaints.
Many a times they are asymptomatic. ${ }^{2}$ But abnormally long styloid process or complex like this may be a causative factor for glassopharyngeal pain; or may be associated with Eagles syndrome or it may be found in tonsillar bed during surgeries on tonsil.2,3,4 Sometimes this may be a cause for swelling in submandibular region as the enlarged styloid process may displace the gland laterally. ${ }^{15}$

CONCLUSION: Abnormally long styloid process either due to ossified stylohyoid ligament or ossified stylohyoid complex is associated with various clinical conditions. A good knowledge of this type of anomaly will be of help to surgeons.

\section{REFERENCES:}

1. Colby CC, Del Gaudio JM. Stylohyoid complex syndrome: a new diagnostic classification. Arch Otolaryngol Head Neck Surg. 2011; 137(3):248-52. doi: 10.1001/archoto.2011.25.

2. J. Skrzat, I. Mroz, J. Walocha, J. Zawilnski, J. K. Jaworek; Bilateral ossification of the stylohyoid ligament. Folia Morphol.2007; 66(3): 203-206. ISSN 0015-5659.

3. Patrica Collins. Development of Head and Neck. In Gray's Anatomy. The Anatomical Basis of Clinical Practice. ed by Susan standring. $40^{\text {th }}$ ed. Churchill Livingstone Elsevier 2008. P 597, 599, 617.

4. Sahana. S. N. Human Anatomy Descriptive and Applied $3^{\text {rd }}$ ed. (Volume 1) Jaminikanta Sen for \& on behalf of The Central Book Agency, Calcutta 1977. P 209- 210.

5. Pranab Mukherjee, Sukanya Palit, Arunabha Tapadar, Hironmoy Roy. Asymmetrical bilateral ossification of stylohyoid chains-a case report with embryological review. International Journal of Anatomical Variations. 2011; 4:134-136.

6. Dutta. A.K. Essentials of Human Anatomy $5^{\text {th }}$ ed [Head And Neck Part 11] Current Books International, Calcutta. 2009; p.27.

7. Victor B Feldman. Eagle's syndrome: a case of symptomatic calcification of the stylohyoid ligaments. J Can Chiropr Assoc 2003; 47(1): 21-27.

8. Shivani Jain, Ashok Bansal, Samrity Paul, and Deepti Vashisht Prashar. Styloid-stylohyoid syndrome. Ann Maxillofac Surg. 2012; 2(1): 66-69.

9. Magotra Rachna, Razdan Shayama. Elongated Styloid Process: Anatomical Variations JK Science: Journal of Medical Education \& Research 2008; vol.10 (4):203-205.

10. Hollinshed WH. Anatomy for Surgeons. 3rd Ed., Philadelphia. J. B. Lippincott Co.1982; 52-53.

11. Ryan D. Murtagha, Jamie T. Caraccioloa and Gaspar Fernandeza. CT Findings Associated with Eagle Syndrome. AJNR 2001; 22:1401-1402.

12. Haroun H S W. Morphometric and radiological evaluation of the stylohyoid complex in man. Ann. of Int. Med \& Den Res2015; 1 (2):49-52.

13. FerrarioVF, Sigurta D, Daddona A, Dalloca. L, Miani A, Tafuro F, Sforza C. Calcification of the stylohyoid ligament: Incidence and morphoquantitative evaluations. Oral Surg, OralMed Oral Pathol1990; 69 :(4). 524-529 (Abstract). 
14. J F Rodríguez-Vázquez, J R Mérida-Velasco, S VerdugoLópez, I Sánchez-Montesinos, J A Mérida-Velasco Morphogenesis of the second pharyngeal arch cartilage (Reichert's cartilage) in human embryos. J Anat. 2006 February; 208(2): 179-189. doi: 10.1111/j.14697580.2006.00524.xPMCID: PMC2100189.
15. Fanibunda K, Lovelock DJ. Calcified stylohyoid ligament unusual pressure symptoms Dento maxillo facial Radiology 1997; 26; 249-251.

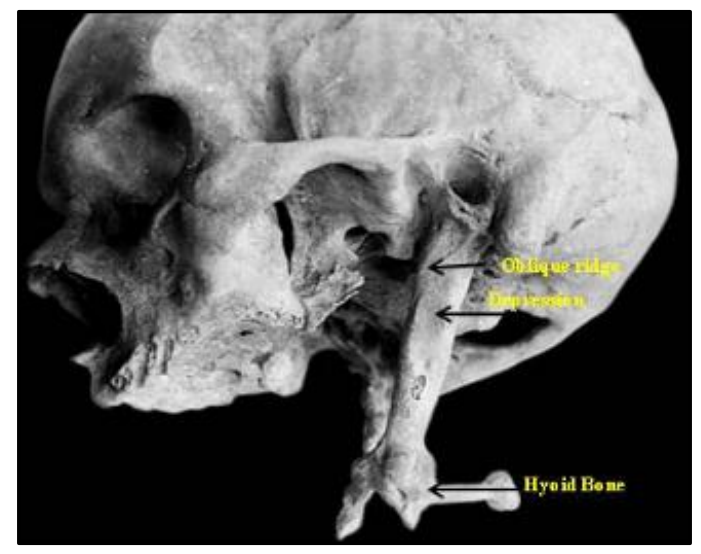

Fig. 1: Left Lateral view of Skull to show stylohyoid complex

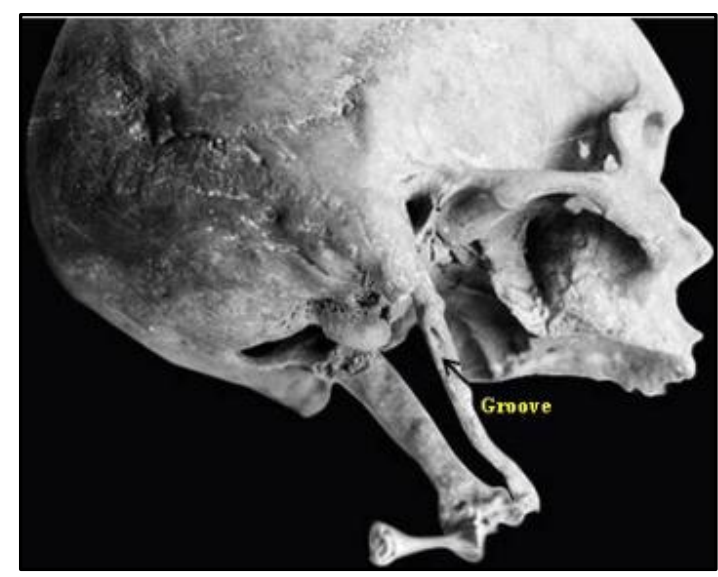

Fig. 2: Right Lateral view of Skull to show stylohyoid complex Complexes

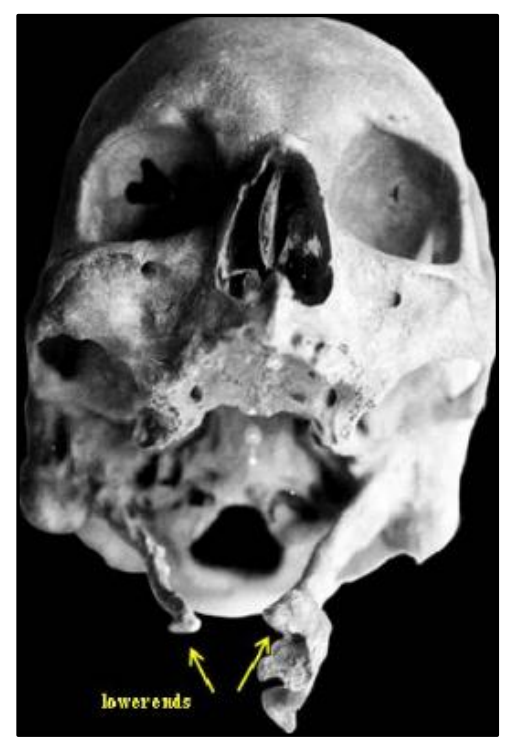

Fig. 3: Skull From Inferior aspect Showing bilateral stylohyoid complex 